\title{
Rubber-band ligation for hemorrhoids in a colorectal unit. A prospective study
}

\author{
J. C. Bernal, M. Enguix, J. López García, J. García Romero and R. Trullenque Peris \\ Service of General Surgery. Hospital General Universitario. Valencia, Spain
}

\begin{abstract}
Introduction: nowadays the rubber band ligation technique is one of the most worldwide used and effective treatment of the hemorrhoidal disease.

Objectives: our study has as a goal to analyze the success or failure of the rubber band ligation in hemorrhoids grade 1,2 and 3 , to analyze their complications and to see if all symptomatic hemorrhoids should be treated with ligation at the first visit.

Patients and method: a prospective and descriptive study was designed for patients who came to the Colorectal Unit with hemorrhoidal disease from September 1997 to December 2001. First, second and third degree patients were treated according to the classification of hemorrhoids of St. Mark's Hospital. The technique of ligation after Barron was applied.

Results: from 261 patients with a mean age of 48.3 (range: 16-86), 181 (99 M/82 W) have been treated with Barron's method and 80 with rich fiber diet and water.

Rectal bleeding was the most common symptom (91.16\%). Anuscopy showed hemorrhoidal disease in all the cases.

From 181 patients, 19.33\% were hemorrhoids degree I, $51.93 \%$ degree II and $29.83 \%$ degree III. Two hundred and eighty-seven ligation sessions were done and the balance of ligations per patient was 2.45 and 1.5 rubber band per session. The $32 \%$ of the patients referred pain after ligation. A $13.81 \%$ of cases were operated due to persistent rectal bleeding or hemorrhoidal prolapse.

Conclusions: symptomatic hemorrhoids degree I and II with a short clinical history should be treated initially with a rich fiber and water diet.

The technique of Barron is an effective therapy to treat the hemorrhoids degree 1, 2 and in 74\% of success in cases with degree 3 .
\end{abstract}

Key words: Ligation. Hemorrhoidal disease. Rectal bleeding. Rubber band.

Recibido: 14-01-03.

Aceptado: 24-02-04.

Correspondencia: Juan-Carlos Bernal Sprekelsen. Servicio de Cirugía General y Digestiva. Hospital General Universitario. Valencia. Avda. Tres Cruces, s/n. 46015 Valencia.
Bernal JC, Enguix M, López García J, García Romero J, Trullenque. R. Rubber-band ligation for hemorrhoids in a colorectal unit. A prospective study. Rev Esp Enferm Dig 2003; 96: 38-45.

\section{INTRODUCTION}

Hemorrhoids are considered one of the most frequent diseases of the anal region with a high prevalence (nearly $50 \%$ of proctological visits in a colorectal unit). Its incidence peak is between 45 and 65 years of age, and is more common in males (1). It is the most frequent anorectal pathology with rectal bleeding in primary care (2).

There are a large number of treatments: medical support, instrumental techniques (rubber-band ligation, sclerosis, infrared photocoagulation), and a variety of surgical techniques (Milligan-Morgan, Longo, and other) that have to be used in about $10 \%$ of cases (3).

Nowadays, rubber-band ligation is the most widely used procedure, and it offers the possibility to resolve hemorrhoidal disease without the need for hospitalization or anesthesia, and with a lower incidence of complications when compared to conventional surgery (4). Prior experience with this method in our unit has been reported elsewhere (5), but in the present study we changed our focus and evaluate not only the importance of the diagnosis and treatment of hemorrhoids at present, but also the response to treatment in long-term follow-up. Our study goals include: a) to determine the usefulness to follow a protocol in the management of the hemorrhoid bleeding in a proctologic unit; $b$ ) to evaluate of the success/failure of the rubber-band ligation in grade-I, II, and III hemorrhoids; and c) to analysis of complications due to ligatures. We wanted also to answer the following questions: a) should all hemorrhoids be treated by rubber-band liga- 
tion at presentation (mainly grades I and II)?; and b) should grade III hemorrhoids be treated by ligation?

\section{PATIENTS AND METHODS}

A prospective and descriptive study was designed. The Colorectal Unit at Consorcio Hospital General Universitario de Valencia covers Health Care Area 8 with 326,667 inhabitants. All successive patients visiting our Unit because of hemorrhoidal disease between September 1997 and December 2001 were included. Exclusion criteria included: patients with hemorrhoidal disease grade IV not suitable for rubber-band ligation, and immunosuppressed patients, particularly patients with antiHIV antibody positive.

An "ad hoc" database was set up, which included: age, gender, dates related to past anorectal history or operations, bowel habit, and use of laxatives. Clinical data included: past and present rectal bleeding symptoms, a short history of rectal bleeding (less than 6 months), isolated rectal bleeding episodes, proctalgia, mucus discharge, tenesmus, pruritus/itching, hemorrhoids grades (I-II-III), and complications following ligations. Physical examination included: visual inspection, digital rectal exploration, and anuscopy in all patients. Colonoscopy was done in patients older than 40 years. In patients younger than 40 year, colonoscopy was performed if there was a family history of colorectal neoplasia. Rectoscopy with contrast-enhanced enema was performed in patients refusing colonoscopy.

All patients received a short rectal washout 1-2 hours prior to treatment, with the goal of avoiding bowel movements in the first 24 hours so that ligatures would not be expelled, as was the case in a previous series of 51 patients treated in our hospital (unpublished data).

No antibiotics were administered, except to patients with valvular heart disease or chronic liver disease.

Rubber-band ligation was done with a Heine $20 \mathrm{~mm}$ gauge proctoscope. The ligator used was a McGivney device. Piles were held with McGivney forceps, and the patient was placed in a left lateral position. Ligatures were placed about $1 \mathrm{~cm}$ above the linea dentata after Barron's technique. Two black rubber bands were placed for every pile. Postligation treatment consisted of standard analgesia with pyrazolones $(2 \mathrm{~g} / 8$ hours during the first 48 hours or acetaminophen $500 \mathrm{mg}$ in case of pyrazolone allergy. Patients with severe pain received also nonsteroideal anti-inflammatory drugs with gastric protection.

Follow-up was made at one month, six months, 1 year, and then yearly via a telephone questionnaire. Subsequent ligations were performed at one month after the prior one, if the patient still had symptoms.

We followed the hemorrhoid classification criteria developed at St. Mark's Hospital.
Subject descriptions and group comparisons were performed with a descriptive analysis of the sample by adapting frequency distribution to qualitative variables; quantitative variables were analyzed with both centralization (mean) and dispersion (range) measures. Data analysis was done using the computer program SPSS for Windows (SPSS Iberica, Madrid, Spain).

\section{RESULTS}

A total of 261 patients with hemorrhoidal disease were included in this study. The mean age was 48.3 years (range, 16-86 years). One hundred eighty one patients (99 man/82 women) underwent to rubber-band ligature following the procedure described by Barron. Eighty patients were treated with watery and fiber-rich diet.

Of 181 cases treated by Barron's method, 153 had an anorectal history of several years' standing (84.53\%), and 20 cases had undergone previous anorectal operations. Rectal bleeding was the most common symptom $(91.16 \%)$ followed by anal pain $(39.2 \%)$ and itching $(53.59 \%)$; other symptoms are listed in table I.

Table I. Past history and major clinical symptoms

\begin{tabular}{ll}
\hline Total of patients: 181 & \\
\hline $153(84.53 \%)$ & Previous anorectal disease* \\
$50(27.62 \%)$ & Constipation \\
$18(9.94 \%)$ & Mucus discharge \\
$20(11 \%)$ & Previous anorectal operations \\
$71(39.22 \%)$ & Proctalgia \\
$97(53.59 \%)$ & Pruritus \\
$165(91.16 \%)$ & Long-term rectal bleeding \\
$27(14.91 \%)$ & Tenesmus \\
$25(13.81 \%)$ & Prolonged use of laxatives
\end{tabular}

*Several years with hemorrhoidal disease.

Associated conditions included two cases of previously unknown ulcerative colitis, seven cases with anal fissure, two cases with condyloma acuminata, one case with anal fistula, another with an anal polyp.

A colonoscopy was performed in 72 cases - 67 patients older than 40 years, and five patients younger than 40 (range: 32 and 78 years). Eighteen patients had colonic polyps, 1 case had colon cancer, 2 had ulcerative colitis, and two had chronic nonspecific colitis (Tables II and III).

A barium enema was performed in 29 patients, and was normal in all of them; rectoscopy was carried out in 26 patients, and pathologic findings were detected in 9 of them. Anuscopy evidenced hemorrhoidal disease in all cases (Table II). Of the 181 patients, 32 had grade-I (19.33\%), 95 grade-II $(51.93 \%)$, and 54 grade-III $(29.83 \%)$ hemorrhoids. 
Table II. Colorectal explorations performed in patients

\begin{tabular}{lccc}
\hline Exploration & $\begin{array}{c}\text { Number of } \\
\text { cases from } \\
\text { the total } \\
\text { series }(181)\end{array}$ & $\begin{array}{c}\text { Pathological } \\
\text { results }\end{array}$ & $\begin{array}{c}\text { Negative } \\
\text { results }\end{array}$ \\
\hline Colonoscopy & $72(39.77 \%)$ & $23^{*}$ & 49 \\
Barium enema & $29(16.02 \%)$ & $0^{* *}$ & 29 \\
Rectoscopy & $26(14.36 \%)$ & $9^{* * *}$ & 17 \\
Anuscopy & 181 & 181 & 0 \\
\hline
\end{tabular}

*See text. ${ }^{* *}$ Only the presence of benign or malignant tumors were considered pathological findings: therefore diverticular disease and other non tumoral conditions were excluded. ***Pathological findings were assessed, and the colonic study was completed by colonoscopy.

Table III. Histology of polyps obtained by polypectomy

\begin{tabular}{ll}
\hline Pseudopolyps & 1 case \\
Hyperplastic polyps & 7 cases \\
Tubular adenoma & 4 cases \\
Tubulovillous adenoma & 2 cases \\
Undetermined & 4 cases $^{*}$ \\
\hline
\end{tabular}

*Insufficient biopsy sample.

A total of 445 ligations in 287 sessions were carried out, with a mean of 2.45 ligations per patient and 1.5 ligations per session; $32 \%$ of patients had pain or tenesmus following ligation, whereas $5 \%$ had rectal bleeding and $1 \%$ had vesical tenesmus (Table IV).

Table IV. Complications after rubber band ligation of hemorrhoids (*)

\begin{tabular}{lcll}
\hline Postligation pain & Light: 28 & Moderate:10 & Severe: 7 \\
Rectal bleeding & Light: 8 & Moderate: 0 & Severe: 1** $^{\text {** }}$ \\
Rectal tenesmus & 13 & & \\
Vesical tenesmus & 2 & \\
Headache (postligation) & 1 & \\
Cystitis & 1 & & \\
\hline
\end{tabular}

* Of 181 patients treated using Barron's method. **Required blood transfusion, although no bleeding site was found during two endoscopies (anuscopy first, then colonoscopy).

Twenty-five of 181 patients (13.81\%) underwent surgery due to persistence of rectal bleeding and hemorrhoidal prolapse. In 2 of 35 patients with grade I hemorrhoids, surgery was indicated because of rectal bleeding, in 9 of 92 cases with grade II hemorrhoids due to rectal bleeding and prolapse and in the remaining 14 cases because of grade III hemorrhoids (Table V).

Patients with a recent history of rectal bleeding (less than six months) [80/261 (30,65\%): 44 with grade I, 36 with grade II hemorrhoids] received treatment with a high-fiber and water diet, and remained asymptomatic.
Table V. Surgical treatment after failed rubber-band ligation

\begin{tabular}{ccc}
\hline Grade of hemorrhoids & \multicolumn{2}{c}{ Surgery Milligan-Morgan's procedure } \\
\hline 1 & $2 / 35(5.71 \%)$ & $2 / 181(1.10 \%)$ \\
2 & $9 / 92(9.78 \%)$ & $9 / 181(4.97 \%)$ \\
3 & $14 / 54(25.93 \%)$ & $14 / 181(7.73 \%)$ \\
\hline Total & & $25 / 181(13.81 \%)$
\end{tabular}

All patients were followed up for one year (100\%). From the second year on, follow-up covered not more than $6 \%$ (patients lost to follow-up), a fact that led to the administration of a questionnaire by telephone. This allowed to monitor $85 \%$ of patients the second year, and up to $67 \%$ at year five. The remaining patients could not be contacted.

\section{DISCUSSION}

Causes of hemorrhoidal disease are unknown. Constipation and bowel habit distress have usually been involved, but there is no clear evidence of it. The present study, in fact, has found constipation in only $27.62 \%$ of patients.

Hemorrhoidal stage is useful for therapeutic assessment, but the fact that prolapse grade may change over time should not be overlooked. We think that the major difficulty is to differentiate grade II from grade III hemorrhoids, with inter-observer agreement being impossible for patients with the same grading in different times of their natural evolution. This may somewhat explain therapeutic failure in patients with grade II hemorrhoids (prolapse reduces spontaneously) that become grade III hemorrhoids (prolapse is reduced manually), and some grade III cases progress to grade IV (irreducible prolapse).

Perhaps we should use the classification by Nicholls and Glass (6). This classification states that prolapse itself would be a clear indication for hemorrhoid therapy using rubber-band ligation, whereas grade I and II hemorrhoids would be managed with medical treatment.

The diagnosis of hemorrhoidal disease is made by anuscopy, which allows $100 \%$ of cases to be confirmed. It is important the use of anuscopy and recto-sigmoidoscopy becomes widespread for the etiological diagnosis of rectal bleeding. Colonoscopy may be warranted for patients older than 40 years in view of our findings regarding polyps and other diseases in $32.65 \%$ of cases. Therefore, all rectal symptoms should be studied in a protocolized manner, and anuscopy should complete the patient's study in the following cases: a) patients older than 40 years; b) when hemorrhoids do not seem to be the source of rectal bleeding; and c) when bleeding persists after ligation of hemorrhoids. 
Anuscopy allows complementary information to be obtained in middle-aged adults with rectal bleeding (7), which is important to have in mind since this is the most important symptom in anal tumors (8). Hemorrhoids - grade I and IIwith a short history of rectal bleeding should initially be treated with a high-fiber and water diet $(9,10)$.

In this way, the first step for symptomatic low-grade hemorrhoids is medical treatment: adequate local hygiene, a correct diet, and a stable bowel habit $(11,12)$. Otherwise, if medical treatment fails for grade I and II hemorrhoids, treatment with ligation or other alternatives should be offered (1). Ligation treatment at presentation should be a patient's decision, following informed consent (13).

Barron's method is an efficacious therapy for grade III hemorrhoids, with a success rate of $74.07 \%$ in the present study. Rubber-band ligation is an easy and safe technique in treating symptomatic grade II and III hemorrhoids. Our results are similar to those reported in the literature, where success rates for rubber-band ligation range between 70 and $80 \%$ (14). A meta-analysis comparing different treatments for hemorrhoids showed that band ligation is the first line of non-surgical treatment for grade I to III hemorrhoids, ahead of sclerotherapy and infrareds (14). Band ligation is a safe technique even in patients with cirrhosis and portal hypertension (15), as well as in patients undergoing anticoagulation therapy. Failed band ligation of grade III hemorrhoids makes surgery necessary in a small percentage of cases, mainly in those with persistent prolapse and bleeding.

Nearly $10 \%$ of patients have symptom recurrence after some years (16), and this percentage increases to $40 \%$ at one year in patients with grade III hemorrhoids (17). Most frequent complications after ligation include rectal pain/tenesmus and mild bleeding. Severe complications are rare and include severe bleeding (requiring blood transfusion), perineal sepsis, and urinary retention (18). After ligation, pain/tenesmus develops in $32 \%$ of patients treated with this method, a finding similar to those by other Spanish authors (1). Foreign authors report higher percentages: $84 \%$ of patients have pain on the first day after ligation ( $18 \%$ with moderate to severe pain), and $60 \%$ within the first 48 hours (14\% with moderate to severe pain) (13). Bleeding is a complication that most usually develops between the 5th and 10th day after ligation. Bupivacaine injections can be useful to relieve pain after ligation (19), as can premedication with dextrometorphane, which also reduces pain after ligation (20); however, we did not use the latter. It is important that a safe margin is provided by applying the ligation at about one centimeter above the dentate line; this relieves pain, but increases therapy failures in grade III hemorrhoids.

In conclusion, we would like to highlight the following: a) rubber-band ligation is an effective treatment for grade I and -II hemorrhoids; b) it is effective in $74 \%$ of cases with grade III hemorrhoids, and should therefore be considered as a first-line treatment; c) rectal pain/tenesmus develops in $32 \%$ of cases treated with ligation, but is minimized when only one ligation per session is performed; and d) patients with a short history of rectal bleeding should be initially treated with a high-fiber and water diet.

\section{ACKNOWLEDGEMENT}

We would like to thank Dra. Inocencia Martínez Mir for the review of this article and her statistical approach. Técnico Superior de Investigaciones del Consorcio Hospital General Universitario de Valencia.

\section{REFERENCES}

1. Linares Santiago E, Gómez Parra M, Mendoza FJ, Pellicer FJ. Eficacia del tratamiento hemorroidal mediante ligadura con banda elástica y la fotocoagulación infrarroja. Rev Esp Enferm Dig 2001; 93: 238-42.

2. Hussain JN. Hemorrhoids. Prim Care 1999; 26: 25-51.

3. Enciclopedia Médico-Quirúrgica 1987; 2: 40-685.

4. Pezzullo A, Palladino E. Rubber Band Ligation of hemorrhoids. Five years follow-up. Min Chir 2000; 21: 253-6.

5. Trullenque Peris R, García Moncó P, Fernández Tena JM, Bolufer Cano JM, García Vilanova A, Cano Ivorra J. Tratamiento de las hemorroides con ligadura elástica. Rev Quir Esp 1988; 1: 38-41.

6. Nicholls RJ, Glass RE. In: Coloproctology: diagnosis and outpatient management. Berlin: Spring Verlag, 1985. p. 84

7. Korkis AM, Mc Dougall CJ. Rectal bleeding in patients less than 50 years of age. Dig Dis Sci 1995; 40: 1520-3.

8. Janicke DM, Pundt MR. Anal disorders. Emerg Med Clin North Am 1996; 14: 757-88.

9. Moessgaard F, Nielson Ml, Hansen JB, et al. High fiber diet reduces bleeding and pain in patients with hemorrhoids. Dis Colon Rectum 1982; 25: 454-6.

10. Pérez Miranda M, Gómez Cedenilla A, Loen Colombo T, Pajares J, Male-Jiménez J. Effects of fiber supplements on internal bleeding haemorrhoids. Hepatogastroenterology 1996; 43: 1504-7.

11. Gricar JA, Goodwin SA, Care DG. Hemorrhoids. Manag Care Interface $1998 ; 11: 50-2$.

12. Battochio F, Giacchetto F. Conservative therapy of hemorrhoids. Ann Ital Chir 1995; 66: 761-7.

13. Hardwick RH, Durdey P. Should rubber band ligation hemorrhoids be performed at the initial outpatient visit? Surg Clin North Am 1992; 72: 665-79.

14. Mac Rae HM, McLeod RS. Comparison of hemorrhoidal treatments: a meta-analysis. Can J Surg 1997; 40: 14-7.

15. Pissiotis CA, Komborozos VA, Skrekas GJ. Rubber band ligation of symptomatic internal haemorrhoids: results of 500 cases Dig Surg 2000; 17: 71-6.

16. Konings M, Debets JM, Beaten CG. Rubber band ligation of hemorrhoids. Symptoms almost gone after 6 weeks. Ned Tijdschr Geneeskd 1999; 143: 1841-2.

17. Yárnoz C, Ortiz H. Estado actual del tratamiento de las hemorroides. Cirugía Andaluza 1997; 4: 342-4.

18. Spallanzani A, Richi E, Carriero A, Fundaro S. Rubber band ligation. Our experience. Minerva Chir 1997; 52: 1017-51.

19. Hooker GD, Plewes EA, Rajgopal C, Taylor BM. Local injection of bupivacaine after rubber band ligation of hemorrhoids: prospective and randomised study. Dis Colon Rectum 1999; 42: 174-9.

20. Liu St, Wu CT, Yeh Cc, Ho St. Premedication with dextrometorfan provides posthemorrhoidectomy pain. Dis Colon Rectum 2000; 43: 507-10. 


\title{
Ligadura con banda elástica de las hemorroides en una Unidad de Coloproctología. Estudio prospectivo
}

\author{
J. C. Bernal, M. Enguix, J. López García, J. García Romero y R. Trullenque Peris \\ Servicio de Cirugía General. Hospital General Universitario. Valencia
}

\section{RESUMEN}

Introducción: la técnica de ligaduras con banda para hemorroides constituye hoy en día uno de los tratamientos más efectivos a nivel mundial.

Objetivos: el objetivo de nuestro estudio ha sido valorar el éxito/fracaso terapéutico de las ligaduras en hemorroides grado III-III, analizar sus complicaciones y plantear si todas las hemorroides sintomáticas deben ser tratadas con bandas en la primera visita.

Pacientes y método: se diseñó un estudio descriptivo prospectivo de los pacientes que acudieron a la Unidad de Coloproctología con patología hemorroidal entre septiembre de 1997 y diciembre de 2001. Se trataron a pacientes con hemorroides grado I, II y III según la clasificación del Hospital de St. Mark's. Se empleó la técnica de ligaduras descrita por Barron.

Resultados: doscientos sesenta y un pacientes, con una edad media de 48,3 años (rango: 16-86), de los cuales 181 (99 V/82 M) han sido tratados según el método de Barron. Ochenta pacientes han sido tratados con dieta rica en fibra y agua.

La sintomatología más frecuente la constituye la rectorragia (91,16\%). La anuscopia evidenció patología hemorroidal en todos los casos.

De 181 pacientes, 19,33\% fueron hemorroides grado I, $51,93 \%$ grado II y $29,83 \%$ grado III. Se efectuaron 287 sesiones de ligaduras, siendo la media de 2,45 ligaduras por paciente y 1,5 ligaduras por sesión. Un 32\% de pacientes tuvieron dolor tras la ligadura. Se operó a un $13,81 \%$ por persistencia de rectorragias y de prolapso hemorroidal.

Conclusiones: las hemorroides sintomáticas grado I y II de corta evolución deben ser tratadas inicialmente con dieta rica en agua y fibra.

La técnica de Barron resulta una terapéutica eficaz para tratar las hemorroides grado 1, 2 y en el $74 \%$ de éxito en los casos grado 3 .

Palabras clave: Ligadura hemorroidal. Enfermedad hemorroidal. Rectorragias. Banda elástica.

\section{INTRODUCCIÓN}

La patología hemorroidal puede ser considerada la enfermedad más frecuente de la región anal, con una elevada prevalencia (alrededor de un 50\% de consultas en una unidad de coloproctología) y un pico de incidencia entre los 45 y 65 años, siendo más frecuente en varones (1). Es la patología anorrectal más frecuente en atención prima- ria siendo a su vez la causa más frecuente de hematoquecia (2).

Existen múltiples tratamientos: médico, instrumental (banda elástica, esclerosis, fotocoagulación con infrarrojos), llegando a la indicación quirúrgica en sus distintas variantes (Milligan-Morgan, técnica de Longo, etc.) en un $10 \%$ de los casos (3).

De todos ellos la ligadura con banda elástica es el procedimiento más extendido en la actualidad, ofrece la posibilidad de resolución de la patología hemorroidal sin necesidad de hospitalización ni anestesia, y con una incidencia de complicaciones menor a la cirugía convencional (4). En nuestro servicio existe experiencia previa con esta modalidad de tratamiento (5), pero en el presente trabajo hemos querido dar un enfoque distinto valorando no sólo la importancia del diagnóstico y tratamiento de las hemorroides, sino también la repuesta al tratamiento a largo plazo. Los objetivos del estudio son los siguientes: a) determinar la utilidad de seguir un protocolo en el tratamiento de las hemorragia hemorroidal en una unidad de proctología; b) valorar el éxito/fracaso terapéutico de las ligaduras en hemorroides grado I-II-III; y c) análisis de las complicaciones de las ligaduras. Además, quisimos dar respuesta a las siguientes cuestiones: a) ¿deben tratarse todas las hemorroides con bandas en la primera visita, sobre todo las de grado I y II?; y b) ¿deben se tratadas las hemorroides de grado III con ligaduras?

\section{MATERIAL Y MÉTODOS}

Se diseñó un estudio descriptivo prospectivo. El ámbito del estudio es la Unidad de Coloproctología del Consorcio Hospital General Universitario de Valencia que da cobertura al área de salud 08 que cuenta con 326.667 habitantes, dependiendo de él 15 zonas básicas de salud.

Se incluyó, de forma consecutiva, a los pacientes que acudieron a la Unidad de Coloproctología para tratamiento de patología hemorroidal entre septiembre de 1997 y diciembre de 2001. Los criterios de exclusión fueron: pacientes con patología hemorroidal grado IV al no ser con- 
siderados susceptibles de tratamiento con ligaduras, pacientes inmunodeprimidos, sobre todo VIH positivos.

Se confeccionó una hoja de recogida de datos ad hoc en la que figuraban: edad, sexo, datos relacionados con operaciones y patología anorrectal previa, hábito intestinal y uso de laxantes. Se incluyeron datos clínicos como: valoración de la clínica previa y actual de rectorragias, historia breve de rectorragias considerando como tal a un periodo inferior a 6 meses, episodios de rectorragia aislados, proctalgia, mucorragia, tenesmo, prurito/escozor, grados de hemorroides (I-II-III) y complicaciones postligadura. Las exploraciones comprenden la inspección visual, tacto rectal y anuscopia a todos los pacientes. La colonoscopia se indicó en personas mayores de 40 años. En los menores de 40 años se realizó la colonoscopia si existía historia familiar de neoplasia colorrectal. Aquellos pacientes que rechazaron la colonoscopia, se les realizó una rectoscopia en la consulta de cirugía y se completó el estudio colónico con un enema opaco.

A todos los pacientes se les indicó un lavado rectal con enema 1-2 horas antes del tratamiento con el objetivo de no defecar dentro de las primeras 24 horas y así evitar la expulsión de las ligaduras como se constató en otra serie anterior de 51 pacientes tratados en el hospital (datos no publicados).

No se emplearon antibióticos excepto en pacientes con valvulopatía coronaria o hepatopatía crónica.

La ligadura con banda elástica se realizó con un proctoscopio de Heine de $20 \mathrm{~mm}$ de diámetro. El ligador es el modelo de McGivney con posibilidad de rotación del mango. El nódulo hemorroidal se sujeta con una pinza de tracción acodada de McGivney. El paciente se coloca en posición lateral izquierda. La ligadura se coloca por encima de la línea pectínea (aproximadamente $1 \mathrm{~cm}$ ) según la técnica de Barron. Se colocan siempre dos bandas elásticas de caucho negro por nódulo. El tratamiento postligadura consiste en una analgesia estándar tipo pirazolonas ampollas (una cada ocho horas y durante las primeras 48 horas) o paracetamol $500 \mathrm{mg}$ en caso de alergia a las pirazolonas. En los pacientes que presentaron dolor intenso se asociaron AINE con protector gástrico.

Las revisiones se realizaron al mes, a los seis meses, año y después anualmente mediante encuesta telefónica. Las ligaduras sucesivas se colocaron al mes de la primera ligadura, si el paciente persistía con síntomas.

Hemos seguido los criterios de clasificación de las hemorroides del Hospital de St. Mark's.

Para la descripción de los sujetos estudiados y la comparabilidad de los grupos se realizó un análisis descriptivo de la muestra proporcionando la distribución de frecuencias de las variables cualitativas; las variables cuantitativas se analizaron mediante las medidas de centralización (mediana) y de dispersión (rango). El análisis de los datos fue realizado con el programa estadístico SPSS para Windows (SPSS Iberica, Madrid, España).

\section{RESULTADOS}

Se han tratado a 261 pacientes con patología hemorroidal, con una edad media de 48,3 años (rango: 16-86), de los cuales $181(99 \mathrm{~V} / 82 \mathrm{M})$ han sido tratados con ligadura con banda elástica según el método de Barron. Ochenta pacientes han sido tratados con dieta rica en fibra y agua.

De los 181 casos que fueron tratados con técnica de Barron, se encontraron 153 casos con clínica de varios años de evolución $(84,53 \%)$ y 20 casos con operaciones anorrectales previas. La sintomatología más frecuente la constituye la rectorragia $(91,16 \%)$, seguida por la proctalgia $(39,2 \%)$ y el prurito $(53,59 \%)$, otros síntomas quedan reflejados en la tabla $I$.

Tabla I. Antecedentes y manifestaciones clínicas más importantes

Número total de

enfermos: 181

\begin{tabular}{ll}
\hline $153(84,53 \%)$ & Patología anorrectal previa* \\
$50(27,62 \%)$ & Estreñimiento \\
$18(9,94 \%)$ & Mucorragia \\
$20(11 \%)$ & Operaciones anorrectales previas \\
$71(39,22 \%)$ & Proctalgia \\
$97(53,59 \%)$ & Prurito \\
$165(91,16 \%)$ & Rectorragias de larga evolución \\
$27(14,91 \%)$ & Tenesmo \\
$25(13,81 \%)$ & Uso prolongado de laxantes \\
\hline
\end{tabular}

*Varios años de evolución de patología hemorroidal.

Dentro de la patología asociada destacan 2 casos de colitis ulcerosas no conocidas (proctitis). En 7 casos se evidenció la existencia de fisura anal, 2 casos de condilomas acuminados, 1 caso de fístula perianal, en otro se asoció un pólipo anal.

En 72 casos se practicó colonoscopia, realizándose 67 de las mismas en pacientes mayores de 40 y 5 en menores de 40 años (rango de edad entre 32 y 78 años), en los menores de 40 años por antecedentes familiares de neoplasia colorrectal. Se evidenciaron pólipos intestinales en 18 pacientes, 1 caso con un adenocarcinoma, 2 casos de colitis ulcerosa y 2 de colitis crónica inespecífica (Tablas II y III).

Tabla II. Exploraciones colorrectales

\begin{tabular}{lccc}
\hline $\begin{array}{l}\text { Exploración } \\
\text { complementaria }\end{array}$ & $\begin{array}{c}\text { Número de casos } \\
\text { sobre el total } \\
\text { de serie }(181)\end{array}$ & $\begin{array}{c}\text { Resultados } \\
\text { patológicos }\end{array}$ & $\begin{array}{c}\text { Resultados } \\
\text { negativos }\end{array}$ \\
\hline Colonoscopia & $72(39,77 \%)$ & $23^{*}$ & 49 \\
Enema opaco & $29(16,02 \%)$ & $0^{* *}$ & 29 \\
Rectoscopia & $26(14,36 \%)$ & $9 * * *$ & 17 \\
Anuscopia & 181 & 181 & 0 \\
\hline
\end{tabular}

*Ver texto. **Se considera patológico sólo a la presencia de tumores benignos y malignos, por tanto queda excluida la enfermedad diverticular $u$ otras entidades no tumorales como concepto de patológico. ${ }^{* * *}$ Los hallazgos patológicos fueron corroborados y el estudio colónico completado por colonoscopia. 
Tabla III. Histología de los pólipos de la colonoscopia

\begin{tabular}{ll}
\hline Pseudopólipos & 1 caso \\
Pólipos hiperplásicos & 7 casos \\
Adenoma tubular & 4 casos \\
Adenoma tubulovelloso & 2 casos \\
No determinado & 4 casos* $^{*}$ \\
\hline
\end{tabular}

*Muestra insuficiente.

El enema opaco se realizó en 29 pacientes siendo normales en todos ellos y la rectoscopia en 26 casos siendo patológica en 9 (Tabla II). La anuscopia evidenció patología hemorroidal en todos los casos. De 181 pacientes, 32 fueron hemorroides grado I (19,33\%), 95 hemorroides grado II $(51,93 \%)$ y 54 de grado III $(29,83 \%)$. Se efectuaron 287 sesiones de ligaduras, con un total de 445 , siendo la media de $2,45(445 / 181)$ ligaduras por paciente y 1,5 ligaduras por sesión. El $32 \%$ de pacientes tuvieron dolor o tenesmo tras la ligadura, el 5\% rectorragias y el $1 \%$ tenesmo vesical (Tabla IV).

Tabla IV. Complicaciones postligadura $\left({ }^{*}\right)$

\begin{tabular}{lccl}
\hline Dolor postligadura & Leve: 28 & Moderado:10 & Severo: 7 \\
Rectorragia & Leve: 8 & Moderada: 0 & Severa: $1 * *$ \\
Tenesmo rectal & 13 & & \\
Tenesmo vesical & 2 & & \\
Cefalea postligadura & 1 & & \\
Cistitis & 1 & & \\
\hline
\end{tabular}

*Del total de 181 pacientes tratados con técnica de Barron. **Requirió transfusión de sangre, aunque no se logró objetivar el sangrado en dos exploraciones endoscópicas (primera por anuscopia y después por colonoscopia).

Se operaron a 25 pacientes de los $181(13,81 \%)$ por persistencia de rectorragias y de prolapso (Tabla V). En 2 de los 35 pacientes con hemorroides de grado I, la cirugía fue indicada por persistencia de las rectorragias, en 9 de los 92 pacientes con hemorroides de grado II la indicación fue la hemorragia rectal y el prolapso y en los restantes 14 casos por hemorroides de grado III (Tabla V).

Tabla V. Intervención quirúrgica tras el fracaso terapéutico de las ligaduras

\begin{tabular}{ccc}
\hline Grado de hemorroides & \multicolumn{2}{c}{ Cirugía según técnica de Milligan-Morgan } \\
\hline 1 & $2 / 35(5,71 \%)$ & $2 / 181(1,10 \%)$ \\
2 & $9 / 92(9,78 \%)$ & $9 / 181(4,97 \%)$ \\
3 & $14 / 54(25,93 \%)$ & $14 / 181(7,73 \%)$ \\
\hline Total & & $25 / 181(13,81 \%)$ \\
\hline
\end{tabular}

Los pacientes con historial reciente de rectorragias (menos de seis meses) [80/261 pacientes (30,65\%): 44 con hemorroides grado I, 36 con hemorroides grado II] recibieron tratamiento con dieta rica en fibra y agua permaneciendo asintomáticos.

El seguimiento al año fue del 100\%, no así a partir del segundo año que no pasó del 6\% de los enfermos (dejaron de acudir a la revisión) y obligó a completar el mismo mediante encuesta telefónica, lográndose recuperar al $85 \%$ de los pacientes del estudio. La revisión a los cinco años fue posible en un $67 \%$ de los casos. El porcentaje restante de fallos se atribuye a imposibilidad de localización.

\section{DISCUSIÓN}

Las causas de la enfermedad hemorroidal son desconocidas. El estreñimiento, con alteraciones del hábito intestinal ha sido implicado de forma habitual, aunque no existe plena evidencia que apoye esto. De hecho en la presente serie sólo está en un 27,62\% de los pacientes.

La clasificación de las hemorroides es útil para el asesoramiento terapéutico, pero no hay que olvidar que el grado de prolapso puede variar en el tiempo. Pensamos por ello que la mayor dificultad estriba en diferenciar sobre todo las hemorroides grado II y grado III, siendo difícil que coincidan dos exploradores con la misma gradación hemorroidal en un paciente en diferentes momentos de la evolución de su patología hemorroidal. Esto podría justificar en cierto modo el fracaso terapéutico en pacientes con hemorroides grado II (el prolapso se reduce espontáneamente) que pasan a ser hemorroides grado III (el prolapso sólo se reduce manualmente), e incluso en algunos casos de hemorroides grado III que pasan a ser hemorroides grado IV (el/los nódulos prolapsados no se reducen).

Quizá por ello, debería optarse más por la clasificación de Nicholls y Glass (6). En esta clasificación se indica claramente que el factor prolapso sería el determinante a la hora de tratar las hemorroides con ligaduras, quedando los grados I y II para tratamiento médico.

El diagnóstico de la patología hemorroidal se efectúa con la anuscopia que permite la confirmación en el 100\% de los casos. Es importante la propagación del uso de la anuscopia y recto-sigmoidoscopia en el diagnóstico etiológico del sangrado. La realización de colonoscopia en mayores de 40 años podría justificarse por el hallazgo de un $32,65 \%$ de las exploraciones que evidenciaron la presencia de pólipos intestinales u otras afecciones. Por tanto, toda sintomatología rectal debe ser estudiada de una forma protocolizada y en la cual al menos debe hacerse una anuscopia como mínimo, prosiguiendo las exploraciones en los siguientes casos: a) pacientes mayores de 40 años; b) siempre que las hemorroides no parezcan el origen del sangrado; y c) cuando persista la proctorragia después de la ligadura de las hemorroides.

La anuscopia proporciona información complementaria en adultos de edad media con sangrado rectal (7), hecho importante a tener en cuenta dado que la manifesta- 
ción más frecuente de los tumores anales es esta (8). Las hemorroides grado I y II con historia breve de rectorragias deben ser tratadas inicialmente con dieta rica en fibra y agua $(9,10)$.

De ello se deduce que el primer escalón en las hemorroides sintomáticas de bajo grado es el tratamiento médico: adecuada higiene local, dieta correcta, regulación del hábito gastrointestinal $(11,12)$. No obstante, cuando fracasa el tratamiento médico en las hemorroides grado I y II, se debe proponer el tratamiento con ligadura $\mathrm{u}$ otra alternativa (1). La aceptación del tratamiento con ligaduras en la primera visita debe ser por decisión del paciente y previo consentimiento informado (13).

La técnica de Barron resulta una terapéutica eficaz para tratar las hemorroides grado III con un éxito del $74,07 \%$ en nuestra serie. La ligadura con banda elástica es una técnica fácil y segura en el tratamiento de las hemorroides sintomáticas grado I, II y III. Nuestros resultados son similares a datos extraídos de literatura publicada donde se observan series en las que el éxito con ligadura con banda elástica oscila entre el 70 y $80 \%$ (14). En un metanálisis comparando diferentes tratamientos de las hemorroides, es la ligadura con banda la primera línea de opción terapéutica no quirúrgica para las hemorroides grado I a III, por delante de la escleroterapia e infrarrojos (14). La ligadura con banda elástica es una técnica segura en pacientes con cirrosis e hipertensión portal (15), así como en pacientes sometidos a tratamiento con anticoagulantes, previa reversión y control del índice de Quick. $\mathrm{El}$ fracaso terapéutico de la ligadura con banda en las hemorroides grado III hace necesaria la cirugía en un pequeño porcentaje de casos justificada la mayoría de las veces por la persistencia del prolapso y el sangrado.

Cerca de un $10 \%$ de los enfermos sufren recurrencia de los síntomas tras unos años del tratamiento inicial (16), hasta un $40 \%$ de fracasos al año en las hemorroides grado III (17). Las complicaciones postligadura que se presentan con mayor frecuencia son el dolor/tenesmo rectal y la rectorragia leve. Las complicaciones graves son poco frecuentes: sangrado "importante" (requiere transfusión sanguínea), sepsis perineal, retención urinaria (18). El dolor/tenesmo postligadura aparece en una cifra no despreciable del $32 \%$ de los pacientes tratados con esta técnica similar a la de otros autores nacionales (1). Otros autores obtienen unos porcentajes más altos con un $84 \%$ de dolor en el primer día, un $18 \%$ de dolor moderado a severo, un $60 \%$ global de dolor en las primeras 48 horas y un $14 \%$ de dolor moderado a severo (13). La hemorragia es una complicación que se presenta más frecuentemente entre el $5^{\circ}$ y $10^{\circ}$ día postligadura. Las inyecciones de bupivacaína pueden ser útiles para reducir el dolor postligadura (19), así como la premedicación con dextrometorfano que también disminuye el dolor postligadura (20), aunque nosotros no lo hemos empleado. Lo importante es dejar un margen de seguridad, haciendo la ligadura alta, al menos un centímetro por encima de la línea pectínea, lo que disminuye las molestias si bien aumenta los fracasos en hemorroides grado 3 .

Como conclusiones nos gustaría resaltar que: a) las ligaduras con bandas elásticas constituyen un tratamiento efectivo para las hemorroides grado I y II; b) constituyen un tratamiento efectivo en el $74 \%$ de las hemorroides grado III y por tanto deben considerarse como primera línea de tratamiento; c) el dolor/tenesmo rectal aparece en un $32 \%$ de los casos tratados con ligaduras, pero disminuye si nos limitamos a una ligadura por sesión; y d) los pacientes con historia corta de rectorragias deben ser tratados inicialmente con dieta rica en fibra y agua.

\section{AGRADECIMIENTOS}

A la Dra. Inocencia Martínez Mir por la revisión del manuscrito y su enfoque estadístico. Técnico Superior de Investigación del Consorcio Hospital General Universitario de Valencia. 